\title{
Constructing Ethnic Identity in Transylvania through Humour
}

\author{
Noémi TUDOR \\ Transilvania University of Braşov (Romania) \\ Department of Theoretical and Applied Linguistics \\ noemi.tudor@unitbv.ro
}

\begin{abstract}
In this paper, I put forward a comparative/contrastive analysis of ethnic identity on the basis of humorous texts about Romanians and Hungarians living in Romania within the framework of the Script-Based Semantic Theory of Humour (SSTH). The corpus contains fifty jokes taken from websites and social media, books and recordings in which the Romanians are at the centre and the Hungarians are the butt and vice versa. The overall purpose of the study is to illustrate the main topics and stereotypes used in ethnic jokes. In this research, I will show that Romanians and Hungarians joke about similar topics, the most common ones being the "ownership" of Transylvania, rejection of the other, and language distortion but also friendship among Hungarians and Romanians. I also conclude that stereotypes can be attributed to one ethnic group, but there are also shared stereotypes, and some of them can switch from one group to the other depending on the perspective.
\end{abstract}

Keywords: ethnicity, humour, identity, stereotypes, Transylvania

\section{Introduction}

In this paper, I aim to analyse jokes about Hungarians and Romanians, focusing on the ethnic relation they share. The main hypothesis is that ethnic jokes are a reflection of social relations national minorities share with the majority population of a country and vice versa. Thus, I am going to identify the main topics the ethnic jokes evoke and the stereotypes included.

The corpus consists of fifty jokes, which were collected mainly from online resources (forty), eight are taken from joke books, and two are recorded jokes collected from a Szeklers' community from Covasna County.

Why jokes about Romanians and Hungarians? This question has a clear-cut answer. First, Hungarians are the most numerous minority, representing $6.5 \%$ of the total population of Romania, this proportion being higher in Transylvania. 
Second, Popescu (2011), making a quantitative research of ethnic jokes from seven Romanian websites, showed that jokes about two ethnic groups living in Romania - Hungarians and Gipsies - make up the largest category.

The main research questions of this study are: 1 . Which are the common topics Romanians and Hungarians joke about? 2. Are these topics based on identical stereotypes about each other?

The study is divided into four main sections. The following section introduces the theoretical framework of the study and the methodology used. Section 3 takes into consideration a topic-oriented division of the analysis, and in Section 4 some concluding remarks are presented.

\section{Theoretical framework and methodology}

Jokes were considered standard forms of verbal humour, which vary according to subject, description, and length. Verbal humour is defined by Zafiu (2007: 497) as "the intention and/or the capacity to produce statements which can provoke a type of reaction (an emotion/laughter)". ${ }^{1}$ Jokes are described as a species of urban folklore (Zafiu 2007).

The study of ethnic humour started with Davies's research in the early 1990s and has become popular around the world. Ethnic jokes are described by Davies (1990: 307) as being "a means by which the joke tellers ascribe human deficiencies to other ethnic groups in an excessive or ludicrous fashion”. However, Davies shows that not all jokes are indiscriminate, as I am going to analyse it in Section 3.4.

Davies (1990) considers that ethnic jokes can be divided into several categories based on the stereotype they refer to. The most numerous jokes, which seem to be spread throughout the world, are part of two categories: canny jokes and stupidity jokes.

In answering the question why people need ethnic jokes, Davies (1990: 307) points out that the generalized answer can be that we "use jokes about peoples as a means of attaining a greater understanding of the joke-tellers, of the butts of their jokes, and of the links between the two groups".

Why are jokes about Hungarians and Romanians ethnic? First, these jokes fit into the definition of ethnic jokes, which are a form of humour aiming to point out cultural and behavioural differences, referring to a stereotype of a particular ethnic group on the basis of which the punch line is built. Second, the jokes about Hungarians and Romanians adhere to Raskin's criteria. Raskin (1985) describes an ethnic joke taking into account two criteria: 1 . if the ethnic script is removed, the joke is incomprehensible; 2 . the target group can only be replaced by another group

1 The translations from Romanian and Hungarian literature and the translation of the corpus are my own throughout the article. 
if this shares the same script. So, ethnic scripts are shared unconsciously and are commonly known before the production of the joke.

As mentioned in the abstract, in this study, I am going to apply the Script-Based Semantic Theory of Humour (SSTH). It was introduced by Raskin in 1979, being published in Semantic Mechanisms of Humor in 1985. Even if many saw in this linguistic theory the model proposed by the Incongruity Theory, Raskin himself does not agree. SSTH is applicable especially to short jokes that end up with a punch line, this being the kind of jokes I will analyse.

For a joke to be humorous, it has to fulfil two conditions. Firstly, it has to be compatible, fully or in part, with two semantic scripts, and, secondly, these two scripts should be opposite, overlapping fully or partially.

Hence, scripts that occur in ethnic jokes are two possible contradictory scripts:

one based on events in the life of real people, the other a wild fantasy based on the comic convention that they possess some unwanted human quality to an absurd degree. The ethnic joke is a misleading tale that begins as a plausible account of a real people and then suddenly switches to an absurd script based on a well-known, established convention. (Davies 1990: 320)

Why analysing jokes about people living in Transylvania? As mentioned previously, Hungarians are the most numerous in this region, living together with Romanians for hundreds of years. Transylvania can be described as "a blurred boundary, an area of ethnic ambiguity far from the dominant centre, whose people provide a ready-made butt for ethnic jokes" (Davies 1990: 313), the dominant centre being the Romanians living in historic Moldova and Țara Românească and the people of Hungary (Davies 1990: 313). Davies seems to consider that the butts of ethnic jokes usually live on "the geographical periphery of the nation" (1990: 310), which is not the case in Romania. Not the geographical distance is the core of ethnic jokes but differences in "language, culture, behaviour, and values, but they are only told and can only be told because of basic similarities between all of them" (Davies 1990: 313).

In this respect, I am going to use the following terminology to describe the dominant group and the peripheral group. Romanians, when being the joke tellers, are the central group; Hungarians, when being the butts of the jokes, are the others, or the periphery. These roles switch when Hungarians become the joke tellers and the Romanians the butts.

I have to conclude with Davies's words: "the butts of the jokes are seen by the joke-tellers as a comic, distorted reflection of themselves, not as alien, unfamiliar, and inscrutable but as ambiguous, eccentric, and thus amusing peoples" (Davies 1990: 314). Therefore, even if there are unconscious similarities, the central group is joking because of small differences that exist between the joke tellers and the butts. 
Is humour an act of friendliness or attack in interethnicity? Zafiu (2007) introduces the opposition of inclusive humour (to laugh with someone), which shows the cohesion/the unity, and exclusive humour (to laugh at someone), which transforms the butt into a victim through aggression. Davies shows that people whom we are laughing at, standing geographically or symbolically at the periphery, are "a slightly strange version" of ourselves (Davies 1998: 1). In this case, the central and the peripheral groups can live in hostile, conflictual, peaceful, friendly relations or even indifference. Schwartz (1973), analysing the relationship existing between Americans and Polish people who live in America, considers that ethnic jokes are insults, showing hatred.

Popescu (2011) does the first linguistic analysis of ethnic humour about Hungarians, and, as in Zafiu (2007), her main point is that jokes are a reflex of verbal humour. This is also my presupposition. From her quantitative analysis, having in focus seven joke websites, it results that there are 345 jokes about Scots, 303 about Jews, 297 about Gipsy people, 188 about Hungarians, etc. If I exclude those people who do not live in large numbers in Romania, especially in Transylvania, we understand why I focus here especially on jokes about Hungarians. Jokes about Gipsies will be dealt with in a future research.

Prosan and Tudor (2020 - forthcoming), analysing humorous texts about Hungarians and Romanians on the basis of a sociolinguistic framework, show that stereotypes are criticized by way of jokes. They establish that there are common topics along which Hungarians and Romanians talk about each other in jokes (misuse of language, obsession of territory, offensive attitude, desire to get rid of each other, etc.). Making the distinction of identity between Hungarians and Szeklers, they conclude that Szeklers are an ethnic group which cannot be assimilated either by Hungarians or by Romanians. Even if it is mainly the Romanians who insult Hungarians, holding negative stereotypes, they show that there are jokes that foreground friendship and peaceful relations. In this paper, I propose a comparative, topic-based analysis, moving forward with the ideas presented in the previously mentioned study.

In order to understand the viewpoint in my analysis, I shall explain the difference between Hungarians and Szeklers (Hu. Székely, Ro. Secui). This name is given to the Transylvanian Hungarians, especially to those who are living in Harghita, Covasna, and part of Mureş counties, the land known as Szeklerland (Hu. Székelyföld, Ro. Tinutul Secuiesc). Even if in the census of 2011 there is no distinction between Hungarians and Szeklers, one should know that there is a contrast in traditions, religion, history, culture (folk costumes and even an alphabet), etc. between people living in Hungary and speakers of Hungarian living in Transylvania. What is more, the Hungarian language Szeklers use is full of regionalisms and archaisms. In this paper, there is no difference made between Szeklers and Hungarians. Drawing on Săftoiu's (2017) analysis on the construction of ethnic categories of Romani and 
Gipsy, where Romani is considered an ethnic group, a category not constructed yet, and Gipsy an ethnic category, it appears that the Szekler category is not constructed yet in the Romanians' collective mentality. Thus, Romanians call the speakers of Hungarian living in Transylvania Hungarians. However, focusing on the jokes told by Hungarians (people who speak Hungarian as a native language and who live in Transylvania), they call themselves Szeklers.

In short, the purpose of this paper is to analyse ethnic jokes about Hungarians and Romanians, which illustrate the relationship between these two ethnic groups, focusing on the main topic the jokes are about and the stereotypes included. In order to answer the research questions, I am going to use a pragmatic framework and apply the Script-Based Semantic Theory of Humour (Raskin 1985). An interdisciplinary analysis is needed as well. Therefore, in my analysis, I am going to use phonetics, morphology, syntax, and semantics in order to fulfil the linguistic analysis of ethnic jokes.

\section{Main topics identified in ethnic jokes}

In the following section, I am going to present the main topics identified in the corpus. Thus, Section 2.1 deals with the history of Transylvania and analyses the stereotypes produced by the desire to demonstrate that Transylvania is one's territory, Section 2.2 discusses the idea of isolation of Romanians and Hungarians, Section 2.3 focuses on language use and language distortion, and Section 2.4 shows that beyond identity crises and the need of ethnic stability friendship exists between Hungarians and Romanians.

\subsection{The history of Transylvania - A topic in ethnic jokes}

The following section has in focus jokes that are constructed around the interpretation of the ownership of Transylvania. We are going to observe that both the Romanians and the Hungarians want to demonstrate that Transylvania is their territory. In this respect, I must present shortly the main historical events that have had this effect.

In time, there has always been a conflict generated by the wish of demonstrating the ownership of Transylvania. This has had as a result the Romanians' and Hungarians' wish to establish whom this territory belongs to. Transylvania, the historical region located in the heart of Romania, has been dominated by different countries throughout the centuries. First, it was part of Dacia (until 106), then of the Roman Empire and was overrun by tribes. It is said that also Bulgarians ruled here starting from the $9^{\text {th }}$ century. Gelou ruled Transylvania before it became controlled by the Kingdom of Hungary (according to Gesta Hungarorum) in 1003. Starting from this point until 
1526, Transylvania had the status of voivodeship as part of the Kingdom of Hungary. In 1570, Transylvania became Principality of Transylvania. In 1687, Transylvania was attached to the Habsburg Empire; then, after 1867, became part of the Austro-Hungarian Empire. After World War I, the Union was proclaimed, Transylvania becoming part of Romania. During World War II, Transylvania was still a motif of disagreements, but after the end of the war Transylvania became an integral part of Romania.

An exhaustive presentation of the historical facts is not the goal of this study. However, we need to understand where this problem arose to be able to understand why it has generated so many humorous texts over time.

(Ro.)

Legenda spune că primul om care a apărut în Transilvania a fost un ungur. Şi ... după ce a descălecat de pe cal să bea apă, când s-a întors nu a mai găsit calul, ci numai un bilețel, pe care scria: Mulțam' fain!

(Eng.)

The legend says that the first man who appeared in Transylvania was Hungarian. And ... after he had dismounted from his horse to drink some water, when he came back, he didn't find his horse, just a note which said: Thanks a lot!

This joke is one of the most well-known jokes. It occurs in many sources and variants. All of them keep the semantic scripts, the oppositions, and the punch line but differ in form. I have chosen (1) considering that I found it on five websites, in online joke recordings, and I also heard it from people who shared jokes during the construction of the corpus. Another popular variant takes a poetic form, but there is no change in content, except the main character of the joke, who is Attila, a Hungarian ruler, and some semantic-switch triggers, which enrich the joke.

As presented in the methodological part, I am going to use the Script-Based Semantic Theory of Humour. The first step is to divide the joke, identifying the two opposed scripts. I also determine the script switch-triggers and the punch line.

Script A: When Hungarians arrive in Transylvania, their wish is satisfied because they seem to be the first who conquer the territory. Script A: [Transylvania is a Hungarian territory].

Script-switch trigger: first, the meaning of the word legend (Cambridge online dictionary: "a very old story or set of stories from ancient times, not always true, that people tell about a famous event or person") and, second, the disappearance of the horse.

Script B: Stereotypically, Romanians are presented as thieves. Hence, the horse was taken by the Romanians. As a consequence, Romanians were the first people on the land. Script B: [Transylvania is a Romanian territory].

Punch line: the content of the note (Thanks a lot!). 
The two scripts are related by the missing horse. The second script evoked by the joke can be decoded on the basis of general knowledge (identifying the stereotype that Romanians are thieves) and also once the punch line is uttered: Thanks a lot! (Ro. Mulțam' fain!).

The analysis of the punch line needs to be done: instead of a horse, the Hungarian finds a note having on it the following message: Thanks a lot! (Ro. Multam' fain!). The English translation does not reflect the meaning completely. First, this expression shows the satisfaction and gratitude. It is addressed to a Hungarian to thank for a gift or favour done by him, in this case, for the horse and for the opportunity to demonstrate the ownership. Mulțam' fain! is the regional variant of Mulțumesc frumos!, emphasizing the regional use of Romanian language.

(Hu.)

Trianonban tárgyalnak az országok további sorsáról a világháború után. A tárgyalás közepén jelentkezik a magyar küldött, hogy szólni kíván. Felszólítják.

-Én csak azt szeretném mondani, hogy mikor mi idejöttünk a Kárpát-medencébe, az éjszaka ellopták a románok a lovainkat.

A többiek nem igazán értik, kérdi az elnök, szeretné-e a magyar, ha a hozzászólását jegyzőkönyvbe vennék.

- Á, nem, nem kell. Csak úgy mondtam...

A tárgyalás folytatódik, megint szólni kíván a magyar:

-Én csak azt szeretném mondani, hogy mikor mi idejöttünk a Kárpát-medencébe, az éjszaka ellopták a románok a lovainkat. Megint kérdik, jegyzőkönyvbe akarja-e vetetni? Mondja:

- Nem kell, csak úgy mondtam... A tárgyalás folytatódik, a magyar megint szólásra kér engedélyt:

- Én csak azt szeretném mondani, hogy mikor mi idejöttünk a Kárpát-medencébe, az éjszaka ellopták a románok a lovainkat. A román küldöttnek már vörös a feje! Üvöltve kifakad:

- De hisz akkor még itt sem voltunk! Mire a magyar:

- Na, ezt vegyék jegyzőkönyvbe...

(Eng.)

At Trianon, it is debated what happens to each country after the War. In the middle of the discussions, the Hungarian who was sent to the negotiation wants to speak.

"I just want to tell you that when we arrived in the Carpathian Basin, the Romanians, during the night, stole our horses."

The others didn't get the idea and the president asks if he wants the words to be recorded.

"Oh, no, there’s no need! I just said it with no purpose." 
The discussions went on, but the Hungarian wants again to speak:

"I just want to tell you that when we arrived in the Carpathian Basin, the Romanians, during the night, stole our horses."

He is asked again if there is a need to record his intervention.

"Oh, no, there's no need! I just said it with no purpose."

The debate goes on, but the Hungarian again wants to tell them something.

"I just want to tell you that when we arrived in the Carpathian Basin, the Romanians, during the night, stole our horses."

The Romanian delegate blushes and starts shouting:

"We weren't even there then."

The Hungarian:

"Please, do record this!"

The second joke seems to evoke the same story but from a different perspective. After World War I, in order to establish the borders of Hungary and other countries (Austria, Croatia, Romania, etc.), on the $4^{\text {th }}$ of June 1920, the Treaty of Trianon is signed. This event was understood by Hungarians as the most catastrophic moment of their history. The joke shows an interaction that takes place at the moment of negotiation.

Script A: The Hungarian wants to remind the people who are negotiating the status Transylvania is going to have after the war that when they arrived in Transylvania the Romanians were already there and stole their horses. As stereotypically Romanians are thieves, the horses were taken by Romanians. As a consequence, Romanians were the first people on the land. Script A: [Transylvania is a Romanian territory].

Script-switch trigger: no need to record someone's intervention, the Romanian's non-verbal reaction (blushing).

Script B: Romanians cannot accept that they are stereotypically considered thieves. Hungarians know that if they recall this event, Romanians will lie. Romanians lie about the fact that they took the horses, and they defend themselves saying that they were not in Transylvania then. Script B: [Transylvania is a Hungarian territory].

Punch line: the Hungarian's words (Please, do record this!).

Applying a pragmatic analysis, the joke illustrates that the speaker's communicative intention is not recognized by the hearer(s). The speech event is the moment of signing an important treaty, which has historical relevance and shows what the roles of each nation are from a historical point of view. Deciding whether Transylvania is a Romanian or Hungarian territory is a confirmation of the status this region had before the Great War. The perlocutionary effect of the Hungarian's words (I just want to tell you that when we arrived in the Carpathian Basin the Romanians, during the night, stole our horses.) is relevant. What the Hungarian intends via his utterance is to get the Romanian say that Romanians were not in Transylvania at the moment of the conquering. The perlocutionary effect of the 
Romanian's words is that he cannot be a thief. The two scripts are related by the stereotype that Romanians are thieves.

Concluding, after the analysis I had, applying SSTH to (1) and (2), this section shows that script opposition remains the same [Transylvania is a Hungarian territory] vs. [Transylvania is a Romanian territory]. The only factor which activates one script or another is from whose perspective the joke is told. The punch line illustrates two possibilities: 1. From a Hungarian perspective, the punch line activates the script [Transylvania is a Hungarian territory]; 2. From a Romanian perspective, the punch line activates the script [Transylvania is a Romanian territory]. The stereotypes held by (1) and (2) remain the same. In both jokes, not depending on the perspective, Romanians are thieves and Hungarians are conquerors.

\subsection{The isolation of Hungarians in Romania and of Romanians in Transylvania}

The following section presents how Hungarians and Romanians react to the necessity of living together in the same country. I am going to analyse a Hungarianoriented joke and a Romanian-oriented joke to be able to consider the similarities and the differences.

(3)

(Ro.)

Ajung doi unguri în Bucureşti. Fără nici un ban, foame mare, ce se gândeşte unul:

- Hai să ne despărțim şi să cerşim, iar la sfârşitul zilei ne întâlnim să vedem cât a strâns fiecare...

Zis şi făcut! Se despart ei, pleacă fiecare unde crede de cuviință şi, pe înserat, se întâlnesc după cum au stabilit.

- Tu cât ai strâns?

-10 lei...

- Şi cum ai făcut?

- Am fost într-un parc şi am scris pe un carton: Nu am serviciu, am 3 copii de crescut, vă rog să mă ajutați! Dar tu cât ai strâns?

-7.658 de lei.

- Jooooj!!! Dar cum ai făcut?

- Am scris pe un carton: Îmi lipseşte 1 leu să mă întorc în Ungaria.

(Eng.)

Two Hungarians arrive in Bucharest. They have no money and they are very hungry, so the first one says:

"Let's split up and beg for money and, at the end of the day, we'll meet and we'll see how much each of us will have received." 
Said and done! They split up, each of them goes where he thinks is better, and, in the evening, they meet again.

"How much did you get?"

"10 lei..."

"What did you do?"

"I was in a park, and I wrote on a piece of cardboard: I have no job, I have three kids to raise. Please help me! How much did you get?"

"7,658 lei."

"Waoooo! But how?"

"I wrote on a cardboard: I need 1 leu to get back to Hungary."

The common knowledge (Lewis 1969) one needs to share before analysing (3) is that Romania is not considered to be a wealthy country. Being an East European, post-communist country is the reason why many people have had money-related problems, $23.5 \%$ being considered poor (dates extracted from a research made by the National Institution of Statistics in 2017).

Script A: Two Hungarians, being in Bucharest, have no money, and they need to eat something. They decide to split up and beg for some money. The context is not sufficient to understand what were they doing in Bucharest, but it is irrelevant for the analysis. The first Hungarian is going to collect some money in the traditional way: being part of an underprivileged group (unemployed, with many kids), one asks for help. Script A: [man (ethnicity is not an important factor) who needs money to live in Romania] [little money].

Script-switch trigger: 10 lei vs. 7,658 lei.

Script B: The second Hungarian is begging for money in an untraditional way: asking 1 leu to leave Romania and go back to Hungary. Script B: [Hungarian (ethnicity is an important factor) needs money to leave Romania] [a lot of money].

Punch line: the message written on the cardboard (I need 1 leu to get back to Hungary).

Joke (3) presents an interesting point of view: living in Romania, all people share some common stereotypes in which case ethnicity does not influence the stereotype held by the joke. In many European countries, it is considered that Romanians are beggars. This stereotypic knowledge is transferred to all people living in this country. The joke also has the following script opposition: [Romanians are wealthy] vs. [Hungarians are poor]. This opposition can also be interpreted as [Romanians, even if not wealthy, give everything they have to get rid of Hungarians] vs. [Hungarians know that they are not welcome, so they use Romanians' hate to earn some money]. 
(4)

(Hu.)

A négernek, a székelynek és a románnak egyszerre születik gyereke. Mindhárman várnak a szülőszoba ajtaja előtt, hogy végre megláthassák a gyereküket. Egyszer csak kilép a szobából a nővérke:

- Uraim, gratulálok, mindhármuk gyereke egészséges. Csak egy baj van, összekevertük őket. Kérem, fáradjanak be, és válasszák ki a sajátjukat.

Erre a székely egyből berohan, és felkapja a néger gyerekét. Mire az:

- Székely! Nem látod, hogy az az én gyerekem? Teljesen olyan, mint én, a bőre színén is látszik.

Mire a székely:

- Lehet hogy a tied, de amíg ki nem derül, melyik a románé, addig ez nálam marad!

(Eng.)

An African, a Szekler, and a Romanian have a baby at the same time. The fathers are waiting in front of the hospital in order to see their kids. The nurse comes:

"Gentlemen, congratulations, all babies are healthy. But there is a problem: we have mixed them up. Come in and try to find your own child."

The Szekler goes in quickly and raises the black child. The African says:

"Szekler! Can't you see that's my child? He's like me, you can see after its skin colour."

The Szekler answers:

"It is possible that it is yours, but until it turns out which one belongs to the Romanian, this one stays with me."

Script A: Three men are waiting outside the hospital to see their babies. The nurse comes with the good news: all babies are healthy. Script A: [ethnic peace].

Script-switch triggers: mixing the babies up; the necessity to find their own babies; raising the black baby.

Script B: The Szekler prefers to take a child that certainly is not his to risking taking home a Romanian child. Script B: [ethnic conflict].

Punch line: the Szekler's words (It is possible that it is yours, but as long as I do not know which one is the Romanian's, this one stays with me.)

Joke (4) is based on three-nationality construction, in which one participant has the role of building up the punch line. The joke presents an African, a Romanian, and a Szekler. It is important to see that the joke presents the identity of Szeklers. We need to be aware of the fact that citizens living in central Romania, speaking Hungarian as a native language, use the ethnonym Szeklers. Stereotypically they differ from Hungarians who live in Hungary. The text illustrates the ethnic conflict existing beyond daily life between Szeklers and Romanians. It seems that ethnic hate is an innate characteristic of Szeklers. Taking home the enemy is the worst 
a Szekler can do. The balance evoked by Script A is disrupted by the punch line which is constructed around the Szekler's words: It is possible that it is yours, but until it turns out which one belongs to the Romanian, this one stays with me. Citing Davies (1998: 1), "[t]he people at the centre are thus laughing at what appears to them to be a slightly strange version of themselves; almost as if they were to see themselves in a distorting mirror at a fair ground", I should emphasize the minimal distinction existing between Szeklers and Romanians. Thus, the punch line represents the difficulty of choosing their own child on the basis of a new concept - ethnic kinship.

Script B can be interpreted in two different ways which do not exclude each other: 1. describing the Szekler as a racist (a stereotypic behaviour); 2. describing the Szekler as a fearful person (also a stereotypic behaviour), who cannot risk taking home a Romanian because he can harm the micro-society he is part of.

As the analysis has demonstrated, both (3) and (4) can be reduced to the idea of racism and stereotype describing both ethnic groups: joke (3) proves that Romanians are racist, and they would do everything to get rid of Hungarians, while in (4) Hungarians are racist and prefer to take home a total stranger rather than to risk taking home a Romanian.

\subsection{Focus on language use}

Hungarians having linguistic problems is another common topic in ethnic jokes. Romanians are often frustrated by Hungarians' indifference towards the national language. Hungarians are trying to gain their right to speak Hungarian in administration in those communities where they are in the majority. They also argue that they do not have an opportunity to speak Romanian in the closed communities they live in, and when they get the chance they are criticized after the first pronounced words. It seems Romanians and Hungarians cannot establish a common ground, and this fact creates many ethnic jokes sharing the idea of incapable Hungarians.

Many jokes illustrate the fact that Hungarians are not able to speak Romanian correctly, criticizing language defects. As an example, six jokes from the corpus, which were collected taking into account the Romanian perspective, indicate the incapacity of Subject agreement with the Verb Phrase and the fact that Hungarians usually mix the gender of nouns. Hence, morphologic and syntactic distortions show that Hungarians are poor speakers of Romanian. Popescu (2011:188) specifies that language distortion is "an object of ridicule" in jokes about Hungarians, adding also problems at a pragmatic level. Furthermore, phonetic accidents are sources of humour. Besides all these, other jokes present the total incapacity to speak Romanian, as in (5). 
(5)

(Ro.)

O maşină încărcată cu 800 de pâini a luat foc în Harghita. Din păcate toată marfa a fost distrusă pentru că şoferul nu ştia să ceară un extinctor în maghiară.

(Eng.)

A car full of 800 loaves of bread caught fire in Harghita. Unfortunately, the whole goods were destroyed because the driver could not ask for an extinguisher in Hungarian.

Script A: A car caught fire. Everything was destroyed. The fire could not be extinguished because the Romanian driver was not able to ask for help. Script A: [the Romanian driver's fault] [Romanian's incapacity].

Script-switch trigger: same as the punch line: the driver could not ask for an extinguisher.

Script B: A car caught fire. Everything was destroyed. The fire could not be extinguished because, even though it happened in Romania, nobody spoke Romanian except the driver. Script B: [the others' fault] [Hungarians' incapacity].

Script C: A car caught fire. Everything was destroyed. The fire could not be extinguished because, taking into account that the message could be understood non-linguistically, being context-dependent, the Hungarians did not want to help the driver who was Romanian. Script C: [Hungarian racism].

Punch line: the incapacity to ask for an extinguisher (the driver could not ask for an extinguisher).

The irony stands beyond the text and creates a humorous effect: the Romanian has to suffer because of Hungarians. This ironic perspective is visible in all the interpretations the joke can have and in all script oppositions it generates: [capacity] vs. [incapacity], [Romanian's fault] vs. [Hungarians' fault], and [racism] vs. [the impossibility of integration caused by language divergence].

Joke (6) takes us back to Section 2.1 of the study, i.e. the history of Transylvania, although the focus is also on language distortion.

(6)

(Hu.)

Két öreg székely, János és Pista, sétálnak egy erdélyi kisvárosban. Hatalmas utazótáskát cipelő úriember szólítja meg román nyelven Jánost:

- Ne haragudjon, nem tudná megmondani, hogy hol találom a vasútállomást?

- Nem! válaszol félvállról János és továbbsétálnak Pistával.

- De komám - szól Pista - nem kellett volna ennyire rosszindulatúnak lenned, hiszen bizonyosan idegen a városban és nem tudhatja, hol van a vasútállomás!

- Amióta megszülettem, azt hallom tőlük, hogy már 2500 éve itt vannak Erdélyben, mi meg nem, tehát ha ilyen rég itt lakik, kell hogy tudja! - válaszol János. 
(Eng.)

Two old Szeklers, János and Pista, are walking in a small Transylvanian town. A gentleman, carrying a big travel bag, says in Romanian to János:

"Sorry, can you tell me where I can find the railway station?"

"No!" answers János carelessly and walks away together with Pista. Pista says:

"My friend, says Pista, you shouldn't have been so malicious. I think he was a stranger, and he couldn't know where the railway station was."

"From the moment I was born, I hear every time that they have been here in Transylvania for 2,500 years, and we haven't. So, if this is so, and he has been living here ever since, he should know that!” answered János.

In opposition with (5), this joke presents two Szeklers who are able to speak Romanian and understand the Speaker's utterance fully. The scripts activated by the joke and their oppositions are presented below:

Script A: Two Szeklers are walking. They meet a Romanian who asks for directions. One of the Szeklers says he cannot help because he does not know where the railway station is.

Script B: Two Szeklers are walking. They meet a Romanian who asks for directions. One of the Szeklers says he is not able to tell him where the railway station is because he cannot speak Romanian, even if he understands/infers the message.

Script C: Two Szeklers are walking. They meet a Romanian who asks for directions. One of the Szeklers says he does not want to tell him where the railway station is. The Romanian knows where it is as he belongs to this territory.

Script D: Two Szeklers are walking. They meet a Romanian who asks for directions. One of the Szeklers says he does not want to tell him where the railway station is because he should know where it is because he belongs to this territory. If he does not know, it is because Romanians lied about the fact that they were in Transylvania before the Szeklers.

Script-which trigger: János's non-verbal reaction (answers János carelessly and walks away together with Pista), Pista's words (My friend, you shouldn't have been so malicious. I think it was a stranger and he couldn't know where the railway station was.).

Script oppositions: [the wish to tell the stranger where to go] vs. [the refusal to tell the stranger where to go], [capability] vs. [incapability], and [native] vs. [stranger].

Punch line: János's last utterances (From the moment I was born, I hear every time that they have been here in Transylvania for 2500 years, and we haven't been. If this is so, and he has been living here since then, he should know that!).

I should also present a difference in attitude in the central-peripheral relation. Szeklers appear as butts in jokes that Romanians and Hungarians tell. When Romanians are the central group, the butt of every joke is a Hungarian (never a Szekler, no difference in the groups' name). On the other hand, when Hungarians 
(people living in Hungary) are the central group and Szeklers are the butt of jokes, the peripheral Szeklers are seen either in a very similar way the Romanians present them (ironic, bitter, frustrated, presenting language distortion), or, more often, they are considered Romanians. Therefore, in Romania, Szeklers are called Hungarians, whereas in Hungary Szeklers are often considered Romanians or at least foreigners. The Szeklers' identity is lost in this bipolar view. A comparative research can answer the questions related to how Szeklers are more similar to Hungarians or Romanians, finding common stereotypes.

There is also another category of language jokes: Romanians learning Hungarian. The one presented below (7) demonstrates that in Transylvania some Romanians learn Hungarian, especially where they are the peripheral group due to population number, being considered the minority.

(Hu.)

Ez is Széken történt meg. Volt egy nagygazda háztáj. Oda sok szegény asszony bejárt ezt segíteni, azt segíteni, s élelmet is kapott érte. Valamit. Ehhez a nagygazdacsaládhoz járt egy jóízú, öregrendú, román asszony is. Nem elég tisztán tudott magyarul, de azért olyan bizalmas barátságba volt a román a magyarral, mert megsegítették egymást. Egyszer nagy szomorún megy Maria néni ehhez a családhoz, sír. Azt mondja a háziasszony:

- Na, Maria, hát mi baj?

- Jaj, jaj, Zsuzsi néni lelkem. Nagy baj van!

- Hát mi?

- Meghótt a koca, şi [és] megdöglett az édesanyám!

(Eng.)

This also happened in Szék. There was a big house owned by a rich man. There were always some poor women going to help in exchange for food. Or at least something. An old-fashioned fine Romanian woman used to work here. She didn't speak Hungarian too well, but Romanians and Hungarians were in good and strong relations, and they helped each other. Once, Maria went to this family, being very sad. She cried. The lady said:

"Well, Maria, what's the matter?"

"Aah, Zsuzsi, my dear. There’s a big problem!"

"What's that?"

"The sow passed away, and my mom kicked the bucket."

Script A: Rich Hungarians help poor Romanians. The Romanian woman is friend with the Hungarian lady. They have a strong, confidence-based relationship. They communicate via the Hungarian language. The Romanian woman knows Hungarian. Script A: [Romanian speaks Hungarian]. 
Script-switch trigger: The Romanian woman speaks Hungarian, but not too well (She didn't speak Hungarian too well).

Script B: Rich Hungarians help poor Romanians. The Romanian woman is friend with the Hungarian lady. They have a strong, confidence-based relationship. They communicate via the Hungarian language. The Romanian woman does not know Hungarian very well, so she makes mistakes: the semantic confusion between meghótt [+animate] [+human] and megdöglett [+animate] [-human] and the semantic switch. Script B: [the Romanian does not speak Hungarian correctly].

The joke illustrates that people living at the periphery (i.e. Romanians) learn the language of the central group (i.e. Hungarians). Their ability of speaking correctly is questioned. Previously, I have mentioned Popescu's (2011) analysis, which shows that language distortion is a manifestation of the language knowledge Hungarians have. Comparing with joke (7), as also discussed by Davies (1990), I consider that this semantic script is applicable to every peripheral group which speaks the language of the central group.

Focusing on the punch line, apart from the semantic switch mentioned above, one has to identify the regional tendencies. The Romanian woman uses the same regional words the Szeklers use. One can recognize the regional forms meghótt and megdöglett in opposition to the correct forms meghalt and megdöglött. At the same time, the insertion of the Romanian conjunction şi instead of the equivalent Hungarian és should be considered.

To sum up, joke (5) shows the dramatic effect the Hungarians' stupidity can have; the joke concludes that Hungarians cannot speak Romanian. Joke (6) reinforces the historical problem, illustrating at the same time that Hungarians are capable of speaking Romanian, while joke (7) introduces a new perspective: friendliness, suggesting that in Transylvania it is possible that Romanians learn Hungarian and that they make the same mistakes as non-native speakers of the language.

Stereotypically, Hungarians are the stupid ones who cannot learn the national language, while Romanians are those who criticize every linguistic mistake a Hungarian makes.

The stereotypes switch when the relation between groups is inverted. When Hungarians are the central group, they speak Romanian, while the butts (the Romanians) speak Hungarian with the same type of semantic, morphologic, and syntactic mistakes as Hungarians when they are the peripheral group.

\subsection{Friendship among Romanians and Hungarians}

In the final subsection, I present the belief that Romanians and Hungarians can live in peace and have a friendly relationship. As this has already been shown in joke (7), Romanians living in Transylvania, known as ardeleni, in the same community with Szeklers, tend to develop a relation based on companionship, even friendship. 
(8)

(Ro.)

La aniversarea a douăzeci de ani de căsătorie, un ungur cheamă la el o familie de prieteni români. La începutul mesei, gazda ține un toast, încercând să vorbească româneşte cât mai corect:

- Aş vre se molțomesc lui Dumnezeu pentru cei doizeci ani petrecoți alături de soția me...

- Alături de soția mea, îl corectează prietenul român.

- Alături de soția te numai de patru ani.

(Eng.)

At the twenty years marriage anniversary, a Hungarian invites a Romanian family who are his friends. At the beginning of the dinner, the host makes a toast, trying to speak correctly:

"I want to thank God for the twenty years spent next to me wife."

"Next to my wife," the Romanian friend corrects him.

"Next to your wife just four."

Script A: The Hungarian man is in a very good relationship with the Romanian family. The Hungarian makes a toast. The Hungarian's accuracy is not good enough. The Romanian man corrects him. Script A: [friend] [friendship] [RomanianHungarian friendship].

Script-switch trigger: the good relation between the Hungarian man and the Romanian family; the use of the possessive my.

Script B: The Hungarian man is in a very good relationship with the Romanian family. The Hungarian makes a toast. The Hungarian's accuracy is not good enough. The Romanian man corrects him. The Hungarian does not infer the Romanian's utterance. Thus, the Hungarian exposes his relationship with the Romanian woman. Script B: [lover] [adultery] [Romanian-Hungarian love].

The kindness existing between the two ethnic groups goes further. The friendship becomes adultery and friends become lovers. Therefore, the Romanian-Hungarian relationship can be governed by hate, friendship, and love, switching from one to another. Hence, ethnicity is not a relevant factor in the decision taken to answer the following question: What kinds of relationships exist between Romanians and Hungarians?

(Hu.)

Egy román ember egy székelynek:

- Figyu, van pálinkám! 38 fokos!

Mire a székely:

- Lázad van öreg, nem pálinkád! 
(Eng.)

A Romanian tells a Szekler:

"Hey! I have pálinka! It has 38 degrees!"

The Szekler answers:

"You have fever, not pálinka!"

Script A: The Romanian has pálinka and tells the Szekler that it has 38 degrees. [acclaim].

Script B: The Romanian has pálinka and invites the Szekler and tells him that it has 38 degrees.

Script-switch trigger: same with the punch line (You have fever, not pálinka) [invitation]

Script C: The Romanian has pálinka and invites the Szekler and tells him that it has 38 degrees. The Szekler criticizes him. [criticism] [refusal].

We can infer that the pálinka is not as strong as it should be. Compared to the Romanian țuică, which is not as strong, pálinka should have at least fifty degrees.

Punch line: the Szekler's answer (You have fever, not pálinka!).

If we take the figurative meaning, the joke can also oppose the following two scripts: [strong] vs. [weak]. These can denote the people's body structure and mental capacity.

Watching the stereotypes jokes hold, we see that in this respect both Romanians (see Romanian woman) and Hungarians (see Hungarian man) can be lovers. Also, both Romanians and Hungarians love drinking alcoholic beverages, as we have already seen in jokes (8) and (9). This alcoholic dependence is demonstrated by the words toast, pálinka, and degrees (strength).

By way of conclusion, existing relations between people living on the same territory appears to be slightly different from the perspective the dominant group presents (Romanians living in other parts of Romania, except Transylvania). If Romanians share social lives with Hungarians, they could live in harmony, relations being characterized by immoral love, friendship but first of all neighbourhood.

\section{Concluding remarks}

In this paper, I put forward an analysis on the basis of Raskin's (1985) ScriptBased Semantic Theory of Humour, which aimed to identify the common topics Romanians and Hungarians joke about. Jokes were found on websites, books, and recordings. The results show that jokes refer to one of the following topics: 1. history/ ownership of Transylvania, 2. the isolation of Hungarians/Szeklers in Romania by the Romanian central group and of Romanians in Transylvania by the Szekler central group, 3. language distortion Hungarians/Szeklers show when speaking Romanians and Romanians create when they speak Hungarian, and 4. friendship and shared 
lives in Transylvania. I have divided Section 2 into four subsections, which have this thematic organization.

Within the subsections presented above, I compared jokes told by Romanians as the central group about Hungarians, the peripheral group, and jokes told by Szeklers/ Hungarians as the central group about Romanians as the butts. I argued that some jokes present the same main topic, but the focus depends on the perspective (2.1). I also analysed some jokes that present the theme of isolation, which appears in different contexts, the rejection of the other being the most important factor (2.2). Section 2.3 focused on language use and language distortion and the ability of speaking Romanian by Hungarians and Hungarian by Romanians.

The last subsection offers an interesting perspective on collaboration and friendship among Romanians and Hungarians; these appear in strong relation with adultery and drinking alcoholic beverages.

In many jokes, stereotypes are stable. Romanians are thieves and Hungarians/ Szeklers are conquerors, not depending from whose perspective the joke is told (see (1) and (2)). Sometimes the stereotypes switch, determined by the perspective the joke illustrates: Hungarians/Szeklers cannot speak Romanian (5) vs. Hungarians/ Szeklers can speak Romanian (6). There are also some common stereotypes: the Hungarian/Szekler and Romanian racist (see (3) and (4)); the Hungarian/Szekler and Romanian lover (8); the Hungarian/Szekler and Romanian alcohol dependent (9).

The paper has also showed how ethnic identity is perceived by the ethnic groups - Romanians and Hungarians, focusing on self and other, on the centre and on the periphery.

Even if it is a sensitive topic, I consider it as a welcomed first step in the domain which should be improved. Further analysis should be done by reorganizing or reanalysing the corpus. This process can enlarge and enrich the findings.

\section{References}

Davies, Christie. 1990. Ethnic Humor around the World: A Comparative Analysis. Indiana: Indiana University Press.

- 1998. Jokes and Their Relation to Society. Berlin-New York: Mouton de Gruyter. Lewis, David K. 1969. Convention: A Philosophical Study. Cambridge, MA: Harvard University Press.

Popescu, Carmen. 2011. Understanding ethnic humour in Romanian jokes. In Marta Dynel (ed.), The Pragmatics of Humour across Discourse Domains, 173-191. Amsterdam-Philadelphia: John Benjamins.

Prosan, Timea-Noémi Tudor. forthcoming. Ethnic identity in jokes with Hungarians and Romanians. In Stanca Măda-Răzvan Săftoiu-Mihaela Constantinescu (eds), Romanian Humour. Krakow: Tertium. 
Raskin, Victor. 1985. Semantic Mechanisms of Humor. Dordrecht-Boston-Lancaster: D. Reidel Publishing Company.

Săftoiu, Răzvan. 2017. Categoria etnică din perspectivă lingvistică [Ethnic Category from a Linguistic Perspective]. www.diacronia.ro/ro/journal/issue/5/A73/ro/pdf (Last accessed: 1 March 2020).

Schwartz, Alvin. 1973. Witcracks, Jokes and Jests from American Folklore. Philadelphia: Lippincott.

Vöő, Gabriella. 1981. Tréfás népi elbeszélések [Funny Folk Tales]. Bucharest: Kriterion.

Zafiu, Rodica. 2007. Evaluarea umorului verbal [The evaluation of verbal humour]. In Gabriela Pană-Dindelegan (ed.), Limba română. Stadiul actual al cercetării [The Romanian Language. The Current State of Research], 497-507. Bucharest: Editura Universității din Bucureşti.

\section{Web sources}

(1) http://www.bancuri.com/legenda-transilvaniei/

(2) http://www.napivicc.hu/vicc.php?Oj88OTk8JyEkLA==\&tipus=\&PHPSESSID=jl djbkjc

(3) https://adevarul.ro/locale/oradea/cele-mai-tari-bancuri-romani-unguri-deintrebidaca-s-ungur-amcerut-gulast-nu-e-magazin-electronice-1_5a671e50df52 022f75c8bee3/index.html

(4) https://www.missziotours.hu/humor.php?vicc=60

(5) https://fun.regielive.ro/bancuri/unguri/

(6) http://viccfaktor.hu/cimke/roman-viccek/o/7

(7) Vöő 1981: 257-258

(8) https://www.facebook.com/Bancuri/posts/10151514910851268/

(9) www.topviccek.hu/vicckategoria/Szekely?page=8 